\title{
Chemical composition, antioxidant, antimicrobial and Antiproliferative activities of essential oil of Mentha spicata $L$. (Lamiaceae) from Algerian Saharan atlas
}

\author{
Sanaa K. Bardaweel ${ }^{1 *}$ (D), Boulanouar Bakchiche ${ }^{2}$, Husam A. ALSalamat ${ }^{1}$, Maria Rezzoug ${ }^{2}$, Abdelaziz Gherib²
} and Guido Flamini ${ }^{3}$

\begin{abstract}
Background: Mentha spicata (M. spicata) is a member of Lamiaceae that spreads mainly in the temperate and subtemperate zones of the world. It is considered as a rich source of essential oils, which is widely used in pharmaceutical industries and food production. The objectives of the current study were to evaluate chemical composition, antioxidant, antimicrobial and antiproliferative activities associated with the essential oil of M. spicata cultivated in Algerian Saharan Atlas.

Methods: The aerial parts of M. spicata were subjected to hydrodistillation to produce the oil. Chemical identification of the oil composition was conducted by GC and GC-MS analyses. The antioxidant activity of the hydrodistilled oil was studied using DPPH, ABTS radical scavenging and ferric-reducing power assay. Antimicrobial potential was characterized against two microorganisms, signifying Gram positive, and Gram negative bacteria, and one Candida species. The microdilution method was employed to determine the minimum inhibitory concentration (MIC). The oil's antiproliferative effects against three human tumor cell lines were also investigated using the MTT assay, and the toxic doses that yielded $50 \%$ reduction of cell viability $\left(\mathrm{LD}_{50}\right)$ were reported.

Results: Chemical analysis of the essential oil composition revealed 44 unique compounds with oxygenated monoterpenes (67.2\%), followed by monoterpene hydrocarbons (20.8\%), as the most abundant chemical components. Essential oil of M. spicata demonstrated moderate antioxidant activities as well as moderate to weak antimicrobial activities with best susceptibility observed for Gram positive bacteria towards the oil. In addition, anticancer activities that are associated with the oil against three human cancer cell lines were observed with $L_{50}$ values of $324 \mu \mathrm{g} / \mathrm{mL}, 279 \mu \mathrm{g} / \mathrm{mL}, 975 \mu \mathrm{g} / \mathrm{mL}$ against T47D, HCT-116 and MCF-7 cell lines, respectively.
\end{abstract}

Conclusion: The results suggest that $M$. spicata essential oil may have potential value as a bioactive oil, for nutraceutical and medical applications, with its antioxidant, antimicrobial and antiproliferative activities.

Keywords: M. spicata, Essential oil, Chemical composition, Antioxidant, Antimicrobial, Antiproliferative

\footnotetext{
* Correspondence: S.bardaweel@ju.edu.jo

${ }^{1}$ Department of Pharmaceutical Sciences, School of Pharmacy, University of

Jordan, Queen Rania Street, Amman 11942, Jordan

Full list of author information is available at the end of the article
}

(c) The Author(s). 2018 Open Access This article is distributed under the terms of the Creative Commons Attribution 4.0 International License (http://creativecommons.org/licenses/by/4.0/), which permits unrestricted use, distribution, and reproduction in any medium, provided you give appropriate credit to the original author(s) and the source, provide a link to the Creative Commons license, and indicate if changes were made. The Creative Commons Public Domain Dedication waiver (http://creativecommons.org/publicdomain/zero/1.0/) applies to the data made available in this article, unless otherwise stated. 


\section{Background}

Recently, there has been renewed interest in the pharmacological features of aromatic plants that can be ascribed to their essential oils. Commonly, essential oils have been reported as bioactive secondary metabolites. Biological activities, comprising analgesic, antiseptic, sedative, spasmolytic, anesthetic and anti-inflammatory effects have been all reported for essential oils extracted from various plants $[1,2]$. Although essential oils from aromatic and medicinal plants have been acknowledged for their diverse bioactivities since antiquity, it is only recently that methodical studies have been inaugurated to thoroughly investigate their bioactive adequacy in relation to their phytochemical characteristics $[3,4]$. Traditionally, various plant parts have been employed to obtain essential oils, including flowers, leaves, seeds, roots, stems, bark and wood [5]. These oils have been widely utilized in medicines as active ingredients or in cosmetics as fragrances [6-9].

The genus Mentha (Lamiaceae family) includes more than 30 species of herbaceous perennial plants [10-13]. Mints are primarily habitants of temperate provinces of the world and exhibit significant discrepancy in their growth features, aromas and natural habitations [10, 13]. Several species of Mentha are used in folk medicine as flavoring agents and as herbal medicines for various therapeutic applications $[14,15]$. Interestingly, Mentha essential oils were recognized as rich in oxygenated monoterpenes [14]. Controlled by the nature of their chief components, Mentha essential oils have been frequently used in different commercial and pharmaceutical products $[16,17]$.

Mentha spicata L. is distinguished by its characteristic essential oil of commercial and therapeutic importance. It is broadly cultivated in many regions worldwide to commercially produce its essential oil [18-20]. Lately, M. spicata has gained increased scientific interest considering other potential uses of its essential oil, predominantly, as antimicrobial and antioxidant bioactive natural extract [21].

To the best of our knowledge, this is the first study investigating the chemical composition and the biological activity profile of essential oil of $M$. spicata cultivated in the Algerian Saharan Atlas (Laghouat region).

\section{Methodology}

\section{Collection and pretreatment of plant material}

Aerial fragments of wild M. spicata L. (Lamiaceae) at full flowering phase were collected in May 2017, from the Laghouat region (Algeria). The samples were identified at the Department of Agronomy, Faculty of Science, University of Laghouat (Algeria), and the voucher specimens (LGP Ms1-3/05/17) were deposited at the laboratory of Process Engineering, University of Laghouat. The dried plant material was stored in the laboratory at room temperature $\left(25^{\circ} \mathrm{C}\right)$, protected from light, until extraction.

\section{Isolation of the essential oil}

Essential oil was extracted from the dried aerial parts of M. spicata by hydro-distillation using an apparatus of Clevenger type. The extraction was carried out for $4 \mathrm{~h}$ to mix $200 \mathrm{~g}$ of plants in $1500 \mathrm{~mL}$ of distilled water. The extracts were dried with anhydrous sulphate and concentrated under reduced pressure by rotatory evaporator to evaporate water. The pure oil was stored at $-4{ }^{\circ} \mathrm{C}$ until further analyzed. The essential oils yield is demonstrated by the oil quality (in $\mathrm{mL}$ ) obtained for $100 \mathrm{~g}$ of dried material.

\section{Physicochemical properties}

The physicochemical properties, namely refractive index, specific gravity, color, solubility and acid number, were determined following Association of Official Analytical Chemists (AOAC) standard methods [22]. The refractive index and specific gravity were measured at $20{ }^{\circ} \mathrm{C}$.

\section{Analysis of the essential oil}

The essential oil chemical composition assessments and the identification of the main constituents were conducted by GC and GC-MS analyses. GC/MS analyses were performed with a Varian CP-3800 gas-chromatograph equipped with a DB-5 capillary column $(30 \mathrm{~m} \times 0.25 \mathrm{~mm}$, coating thickness $0.25 \mu \mathrm{m}$ ) and a Varian Saturn 2000 ion trap mass detector. Analytical conditions were as follows: injector and transfer line temperatures $220{ }^{\circ} \mathrm{C}$ and $240{ }^{\circ} \mathrm{C}$ respectively; oven temperature programmed from $60{ }^{\circ} \mathrm{C}$ to $240{ }^{\circ} \mathrm{C}$ at $3{ }^{\circ} \mathrm{C} /$ min; carrier gas helium at $1 \mathrm{~mL} / \mathrm{min}$; injection of $0.2 \mu \mathrm{L}$ (10\% hexane solution); split ratio 1:30. The identification of the constituents was based on the comparison of the retention times with those of authentic samples, comparing their linear retention indices relative to the series of $n$-hydrocarbons, and on computer matching against commercial [23] and home-made library mass spectra built up from pure substances and components of known oils and MS literature data $[23,24]$.

\section{Antioxidant activity $D P P H$ radical scavenging activity}

The antioxidant activity of the essential oil based on the scavenging activity of the stable 1,1-diphenyl-2- picrylhydrazyl free radical was determined by the method described by [25].A volume of $0.1 \mathrm{~mL}$ of essential oil from $M$. spicata prepared at different concentrations was mixed with $1.9 \mathrm{~mL}$ of $60 \mu \mathrm{M}$ DPPH methanol solution. The disappearance of the DPPH was measured at $517 \mathrm{~nm}$ after $30 \mathrm{~min}$ of incubation at room temperature. The inhibition percentage of the DPPH radical by the essential oil was estimated using the following equation: Scavenging effect $(\%)=\left[100 *\left(A_{C}\right.\right.$ $\left.\left.-A_{S} / A c\right)\right]$, where $A c$ is the absorbance of the control reaction (containing all reagents except the test sample) and $\mathrm{A}_{\mathrm{S}}$ the absorbance of the tested sample. The concentration of 
oil that could scavenge $50 \%$ of the DPPH radicals $\left(\mathrm{IC}_{50}\right)$ was calculated. Ascorbic acid and BHT were used as standards for comparison.

\section{ABTS radical scavenging activity}

ABTS radical scavenging activity of $M$. spicata essential oil was measured by the ABTS cation decolorization assay as described by [26] with some modifications. The ABTS radical cation $\left(\mathrm{ABTS}^{\bullet+}\right.$ ) was produced by reaction of $7 \mathrm{mM}$ stock solution of ABTS with $2.45 \mathrm{mM}$ potassium persulfate and allowing the mixture to stand in dark at room temperature $\left(25^{\circ} \mathrm{C}\right)$ for $12 \mathrm{~h}$ before use. The $\mathrm{ABTS}^{*+}$ solution was diluted with methanol to give an absorbance of $0.7 \pm 0.01$ at $734 \mathrm{~nm} .20 \mu \mathrm{L}$ of essential oil from M. spicata prepared at different concentrations were allowed to react with $1980 \mu \mathrm{L}$ of the $\mathrm{ABTS}^{*+}$ solution and the absorbance was measured at $734 \mathrm{~nm}$ after $6 \mathrm{~min}$. The scavenging rate and $\mathrm{IC}_{50}$ value were calculated using the equation described for DPPH assay. Ascorbic acid and BHT were used as standards for comparison.

\section{Ferric-reducing power assay (FRAP assay)}

The reducing power of the essential oil was measured by making use of the method described by [27] with some modifications. $0.1 \mathrm{~mL}$ of various concentrations of essential oil in methanol was taken separately and mixed with $2 \mathrm{~mL}$ of $0.2 \mathrm{M}$ sodium phosphate buffer ( $\mathrm{pH}$ 6.6). The diluted sample was then mixed with $2 \mathrm{~mL}$ of $1 \%$ potassium ferricyanide $\left[\mathrm{K}_{3} \mathrm{Fe}(\mathrm{CN})_{6}\right]$ and the mixture was incubated at $50{ }^{\circ} \mathrm{C}$ for $20 \mathrm{~min} .2 \mathrm{~mL}$ of $10 \%$ trichloroacetic acid (TCA) was added to the mixture and centrifuged at $3000 \mathrm{rpm}$ for $10 \mathrm{~min} .2 \mathrm{~mL}$ of the supernatant solution was mixed with $2.5 \mathrm{~mL}$ of distilled water and $0.5 \mathrm{~mL}$ of $1 \%$ ferric chloride $\left(\mathrm{FeCl}_{3}\right)$, and the absorbance was measured at $700 \mathrm{~nm}$. The $\mathrm{IC}_{50}$ value is the effective concentration at which the absorbance is 0.5 and is obtained by the equation described for DPPH assay. Ascorbic acid and BHT were used as standards for comparison.

\section{Antimicrobial activity \\ Microbial strains and growth conditions}

Staphylococcus epidermidis ATCC 12228; a representative of Gram positive, Escherichia coli ATCC 29425; a representative of Gram negative and Candida glabrata ATCC 22553; fungi, were obtained from the Microbial Culture Collection Center of Medicine School at The University of Jordan, Jordan. Microorganisms were grown in nutrient broth medium and incubated, with shaking, at $37^{\circ} \mathrm{C}$ and at $33{ }^{\circ} \mathrm{C}$, for bacteria and candida respectively.

\section{MIC determination}

The minimum inhibitory concentration (MIC) determination, designated as the least concentration at which more than $80 \%$ of the microbial growth is inhibited, was carried out in 96 flat bottom microtiter plates (TPP, Switzerland) according to the microdilution method [28, 29]. Each microorganism was inoculated in each microtiter plate well at an inoculum size of $1 \times 10^{5} \mathrm{CFU} \mathrm{mL}^{-}$ ${ }^{1}$. Positive controls, Ampicillin for bacteria and Amphotericin $\mathrm{B}$ for fungi, and a negative control of the vehicle (DMSO), were prepared under the same experimental conditions. Bacterial testing plates were incubated for $48 \mathrm{~h}$ at $37^{\circ} \mathrm{C}$, whereas Candida plates were incubated for $48 \mathrm{~h}$ at $33{ }^{\circ} \mathrm{C}$, with shaking. To evaluate microbial growth, optical densities were measured at $600 \mathrm{~nm}$ $\left(\mathrm{OD}_{600}\right)$ using a Microplate Reader (Palo Alto, CA, USA).

\section{Antiproliferative activity Cells and cell culture conditions}

The human colon cancer HCT-116, the human breast adenocarcinoma MCF-7, and the human ductal carcinoma T47D cell lines were purchased from the American Type Culture Collection (Rockville, MD, USA). Cells were grown and maintained in Dulbecco's modified Eagle's medium (DMEM, Gibco, Waltham, MD, USA) supplemented with $10 \%$ fetal bovine serum (FBS), and penicillin $(100 \mathrm{U} / \mathrm{mL})$ and were incubated at $37^{\circ} \mathrm{C}$ in a humidified atmosphere of $95 \% \mathrm{O}_{2}$ and $5 \% \mathrm{CO}_{2}$. Cell cultures were passaged every 2-3-days or whenever reaching $80 \%$ confluent. Cells were seeded at a density of $6-8 \times 10^{3}$ cells/ well in 96 -well plates and incubated for $24 \mathrm{~h}$ for adhesion.

\section{Cell proliferation assay (MTT)}

The MTT colorimetric assay was employed to evaluate cell proliferation as previously described [5]. In brief, test samples were prepared by dissolving the essential oil in DMSO followed by further dilution with DMEM medium to reach the desired final concentration. The final DMSO concentration in the assay was kept as low as $0.1 \%$. Test samples containing the desired concentration of the essential oil were added to the wells. After exposure period of $48 \mathrm{~h}$, MTT solution was applied into each well and incubated for $4 \mathrm{~h}$ at $37{ }^{\circ} \mathrm{C}$. Afterward, DMSO was added to each well to solubilize the purple formazan crystals formed. Then, absorbance was read using a micro-plate reader at $570 \mathrm{~nm}$. Doxorubicin was used as the positive control and 0.1\% DMSO in DMEM media as solvent control.

\section{Statistical analysis}

All experiments were conducted in triplicates and results are expressed as mean \pm standard deviation (SD), being analysed using a Student's t-test, with $\alpha=0.05$. The analyses were carried out using IBM SPSS Statistics for Windows, Version 22.0. (IBM Corp., Armonk, New York, USA). 
Table 1 Chemical composition of the essential oil from aerial parts of M. spicatai

\begin{tabular}{|c|c|c|c|}
\hline Constituents & LRI & \%Area & Method of Identification ${ }^{a}$ \\
\hline a-pinene & 941 & 0.7 & MS; LRl; RC \\
\hline sabinene & 977 & 0.6 & MS; LRI; RC \\
\hline$\beta$-pinene & 982 & 1.1 & MS; LRI; RC \\
\hline myrcene & 993 & 0.8 & MS; LRI; RC \\
\hline 3-octanol & 994 & 0.3 & MS; LRI; RC \\
\hline a-terpinene & 1020 & 0.3 & MS; LRI; RC \\
\hline p-cymene & 1028 & 0.2 & MS; LRI; RC \\
\hline limonene & 1032 & 16.1 & MS; LRI; RC \\
\hline 1,8 -cineole & 1034 & 8.7 & MS; LRI; RC \\
\hline (Z)- $\beta$-ocimene & 1042 & 0.3 & MS; LRI; RC \\
\hline (E)- $\beta$-ocimene & 1052 & 0.1 & MS; LRI; RC \\
\hline$\gamma$-terpinene & 1063 & 0.4 & MS; LRI; RC \\
\hline cis-sabinene hydrate & 1070 & 0.8 & MS; LRI; RC \\
\hline terpinolene & 1090 & 0.2 & MS; LRI; RC \\
\hline linalool & 1101 & 0.2 & MS; LRI; RC \\
\hline nonanal & 1104 & 0.1 & MS; LRI; RC \\
\hline cis-p-menth-2-en-1-ol & 1123 & 0.2 & MS; LRI \\
\hline 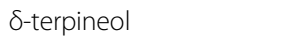 & 1172 & 0.5 & $M S ; L R I$ \\
\hline 4-terpineol & 1179 & 1.5 & MS; LRI; RC \\
\hline a-terpineol & 1191 & 0.3 & MS; LRI; RC \\
\hline cis-dihydrocarvone & 1195 & 3.9 & MS; LRI; RC \\
\hline trans-carveol & 1219 & 0.2 & MS; LRI; RC \\
\hline (Z)-3-hexenyl isovalerate & 1238 & 0.9 & MS; LRI; RC \\
\hline pulegone & 1239 & 0.5 & MS; LRI; RC \\
\hline carvone & 1244 & 49.5 & MS; LRI; RC \\
\hline dihydroedulan IA & 1292 & 0.1 & MS; LRI \\
\hline isodihydrocarvyl acetate & 1329 & 0.6 & MS; LRI \\
\hline cis-carvyl acetate & 1364 & 0.3 & MS; LRI; RC \\
\hline$\beta$-elemene & 1392 & 0.3 & MS; LRI \\
\hline (Z)-jasmone & 1395 & 0,3 & MS; LRI; RC \\
\hline$\beta$-caryophyllene & 1419 & 2.7 & MS; LRI; RC \\
\hline$\beta$-copaene & 1430 & 0.2 & $M S ; L R I$ \\
\hline aromadendrene & 1440 & 0.1 & MS; LRI; RC \\
\hline a-humulene & 1455 & 0.2 & MS; LRI; RC \\
\hline cis-muurola-4(14),5-diene & 1463 & 0.3 & MS; LRI \\
\hline germacrene D & 1482 & 2.1 & MS; LRI \\
\hline bicyclogermacrene & 1496 & 0.7 & MS; LRI \\
\hline germacrene A & 1505 & 0.7 & MS; LRI \\
\hline$\delta$-cadinene & 1524 & 0.2 & MS; LRI \\
\hline spathulenol & 1577 & 0.2 & MS; LRI \\
\hline caryophyllene oxide & 1582 & 0.3 & MS; LRI; RC \\
\hline 1,10-di-epi-cubenol & 1615 & 0.2 & MS; LRI \\
\hline
\end{tabular}

Table 1 Chemical composition of the essential oil from aerial parts of M. spicatai (Continued)

\begin{tabular}{llll}
\hline Constituents & LRI & \%Area & Method of Identification ${ }^{2}$ \\
\hline T-cadinol & 1641 & 0.3 & MS; LRI \\
T-muurolol & 1642 & 0.2 & MS; LRI \\
Monoterpene hydrocarbons & 20.8 & \\
Oxygenated monoterpenes & 67.2 & \\
Sesquiterpene hydrocarbons & 7.5 & \\
Oxygenated sesquiterpenes & 1.2 & \\
Other Compounds & 1.7 & \\
Total identified & $\mathbf{9 8 . 4}$ &
\end{tabular}

${ }^{a}$ Method of identification: MS mass spectrum, $L R I$ linear retention index, $R C$ reference compound

\section{Results}

Chemical composition of the essential oil

The essential oil was extracted by the hydrodistillation of the dried aerial parts of $M$. spicata from the Laghouat region (Algeria), and was analyzed by GC-MS. The yield of the oil was $1.04 \mathrm{~mL}$ per $100 \mathrm{~g}$ plant material, soluble in $80 \%$ alcohol, with a pale-yellow color and persistent aromatic-spicy odor. The refractive index, specific gravity, and acid value of the essential oil were 1.48; 0.88 and 1.30 , respectively, which indicate high quality and purity of the volatile oil.

As shown in Table 1, analysis of the essential oil resulted in identification of 44 compounds, representing $98.40 \%$ of the total oil, with carvone (49.5\%), limonene (16.1\%), 1,8-cineole $(8.7 \%)$, cis-dihydrocarvone (3.9\%), $\beta$-caryophyllene (2.7\%), germacrene D (2.1\%) and $\beta$-pinene $(1.1 \%)$ were the predominating components. The most abundant chemical structure within components was the oxygenated monoterpenes $(67.2 \%)$, followed by monoterpene hydrocarbons (20.8\%), sesquiterpene hydrocarbons (7.5\%) and oxygenated sesquiterpenes (1.2\%).

\section{Antioxidant activity}

The antioxidant activities of essential oil of $M$. spicata were determined by DPPH, ABTS and FRAP. The results are summarized in Table 2. In DPPH, the assessed sample was able to reduce the stable violet DPPH radical to the yellow $\mathrm{DPPH}-\mathrm{H}$, reaching $50 \%$ of reduction with $\mathrm{IC}_{50}$ value of

Table 2 Antioxidant activities of aerial parts of M. spicate essential oi

\begin{tabular}{llll}
\hline & \multicolumn{3}{c}{ Scavenging activity $I_{50}(\mu \mathrm{g} / \mathrm{mL})$} \\
\hline Parameters & DPPH & ABTS & FRAP \\
Essential oil & $3450 \pm 172.5^{\mathrm{a}}$ & $40.2 \pm 0.2^{\mathrm{a}}$ & $215 \pm 4.50^{\mathrm{a}}$ \\
Ascorbic acid & $2.22 \pm 0.04^{\mathrm{b}}$ & $0.82 \pm 0.01^{\mathrm{b}}$ & $2.2 \pm 0.1^{\mathrm{b}}$ \\
BHT & $15.20 \pm 0.02^{\mathrm{b}}$ & $1.42 \pm 0.05^{\mathrm{b}}$ & $18.2 \pm 0.5^{\mathrm{b}}$ \\
\hline
\end{tabular}

Each value in the table is represented as mean \pm SD $(n=3)$. Means not sharing the same letter are significantly different at $P<0.05$ probability level in each column 
Table 3 Antimicrobial activity of aerial parts of M. spicata essential oil measured by MIC $(\mu \mathrm{g} / \mathrm{mL})$

\begin{tabular}{llll}
\hline & \multicolumn{3}{l}{ Antimicrobial activity $\mathrm{MIC}(\mu \mathrm{g} / \mathrm{mL})$} \\
\hline Microorganism & $\begin{array}{l}\text { Staphylococcus } \\
\text { epidermidis }\end{array}$ & $\begin{array}{l}\text { Escherichia } \\
\text { coli }\end{array}$ & $\begin{array}{l}\text { Candida } \\
\text { glabrata }\end{array}$ \\
Essential oil & 32 & 64 & 256 \\
Ampicillin & 2 & 4 & - \\
Amphotericin B & - & - & 2 \\
\hline
\end{tabular}

$(3450 \pm 172.5 \mu \mathrm{g} / \mathrm{mL})$. Relative to the potent antioxidant agents, ascorbic acid $\left(\mathrm{IC}_{50}=2.22 \pm 0.04 \mu \mathrm{g} / \mathrm{mL}\right)$ and BHT $(15.20 \pm 0.02 \mu \mathrm{g} / \mathrm{mL})$, M. spicata exhibits weak antioxidant potential. Interestingly, essential oil of $M$. spicata grown in Iran demonstrated better antioxidant activity $(81.66 \mu \mathrm{g} / \mathrm{mL})$ [30], similar to that reported from Turkey $(77.40 \mu \mathrm{g} / \mathrm{mL})$ [31] and Egypt $(63.80 \mu \mathrm{g} / \mathrm{mL})$ [32].

The total antioxidant capacity was also characterized by neutralization of the radical cation of 2,2'-azino-bis(3-ethylbenzo thiazoline-6-sulphonic acid). The ABTS activity obtained for $M$. spicata essential oil $\left(\mathrm{IC}_{50}\right.$ value of $40.2 \pm 0.2 \mu \mathrm{g} / \mathrm{mL}$ ) was more potent than those described [30] for $M$. spicata grown in Iran $\left(\mathrm{IC}_{50}\right.$ value of $173.80 \mu \mathrm{g} / \mathrm{mL})$.

For Ferric reducing power, the presence of reducing agents in the extracts of plants causes thereduction of $\mathrm{Fe}^{+3}$ - ferricyanide complex to the ferrous form. Therefore, $\mathrm{Fe}^{+2}$ can be assessed byfollowing the increase in the density of blue color in the reaction medium at700 $\mathrm{nm}$ [33]. M. spicata essential oil showed antioxidant activity with an $\mathrm{IC}_{50}$ value of $215 \pm 4.50 \mu \mathrm{g} / \mathrm{mL}$ while ascorbic acid and BHT as a positive control showed $\mathrm{IC}_{50}$ values of $2.2 \pm 0.1$ and $18.2 \pm 0.5 \mu \mathrm{g} / \mathrm{mL}$, respectively. These results suggest that the essential oil of $M$. spicata has a remarkable potency to donate electron to reactive free radicals, converting them into more stable non-reactive species and terminating the free radical chain reaction.

\section{Antimicrobial activity}

The essential oil of $M$. spicata was examined for its antimicrobial activity potential against a panel of pathogenic microorganisms including Gram positive, Gram negative, and fungi (Table 3). Mentha spicata oil demonstrated variable level of antimicrobial activity against all examined microorganisms. Results obtained from minimum inhibitory concentration (MIC) determination indicated that the essential oil was most active against the Gram-positive Staphylococcus epidermidis with MIC value of $32 \mu \mathrm{g} \backslash \mathrm{mL}$.

\section{Antiproliferative activity}

To explore other possible biological activity of the essential oil, M. spicata hydrodistilled oil was further evaluated for its in vitro antiproliferative characteristics on three human cancer cell lines, including human breast adenocarcinoma MCF-7 cell line, the human ductal breast epithelial tumor T47D cell line, and the human colon cancer HCT-116. Antiproliferative activities associated with $M$. spicata oil on the examined cell lines are presented in Fig. 1. The concentration of the oil at which survival was reduced by $50 \%\left(\mathrm{LD}_{50}\right)$ was calculated based on the dose-dependent curves and were $324 \pm 81 \mu \mathrm{g} / \mathrm{mL}$, $279 \pm 52 \mu \mathrm{g} / \mathrm{mL}$, and $975 \pm 156 \mu \mathrm{g} / \mathrm{mL}$ for T47D, HCT-116 and MCF-7 cell lines, respectively. Positive control Doxorubicin $\mathrm{LD}_{50}$ values were in the range of 5$25 \mu \mathrm{g} / \mathrm{mL}$. The anticancer activities that were observed on the three cancer cell lines under examination can be attributed to the significant abundance of some of the most naturally active anticancer components of the oil, such as1,8-cineole and limonene [34].

\section{Discussion}

The data on the chemical composition of Menta spicata L. (Lamiaceae) essential oil cultivated in the Algerian Saharan Atlas has been reported for the first time. Previous studies have shown that monoterpenes, including carvone, limonene, and 1,8-cineole, to be the main components of
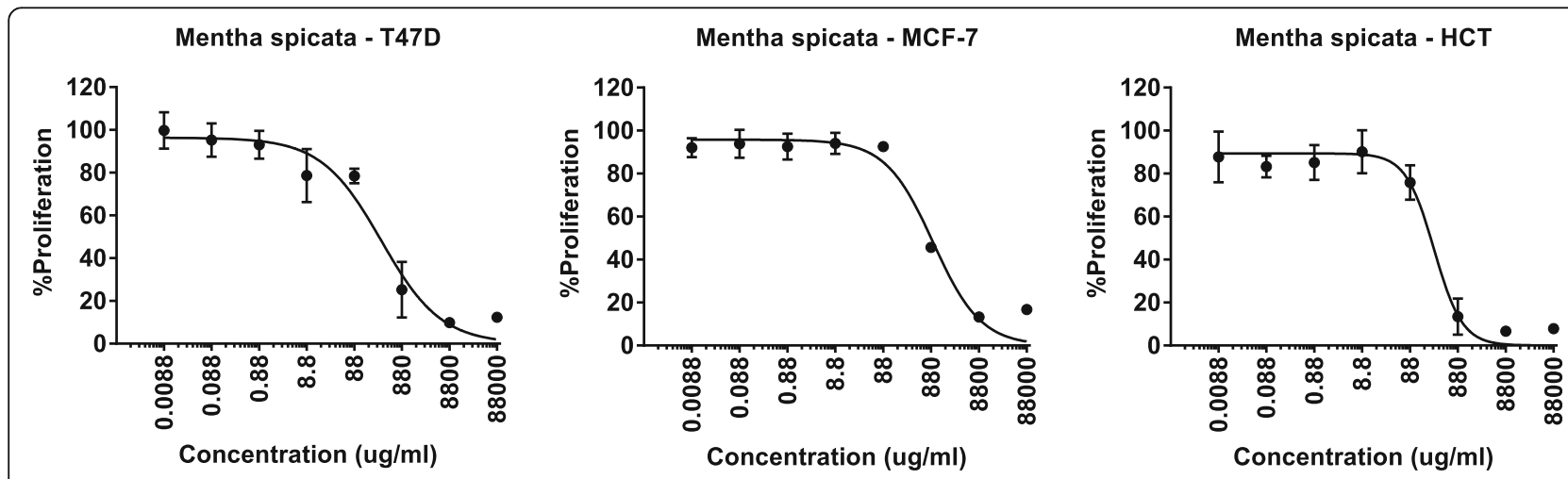

Fig. 1 Antiproliferative activities of aerial parts of M. spicate essential oil on three cancer cell lines, exposure time $48 \mathrm{~h}$ 
the essential oil from M. spicata [35-37]. Similar chemical composition of Mentha spicata essential oil from Bejaia location in Algeria was reported [38]. Interestingly, the essential oil under investigation in this study appears to be richer with some key constituents such as 1,8-cineole and oxygenated monoterpenes. A review of the literature available on this topic reveals that many studies have already been published on M. spicata essential oils chemical composition [39], nevertheless there are no reports on the composition of M. spicata from Algerian Saharan Atlas region. Noteworthy, the composition of these volatile oils varies according to the countries, or the places in the same country. These differences seem to depend on climate changes and other factors like the method and the time of extraction, which can influence essential oil composition [40, 41].

In an effort to characterize the biological activity of $M$. spicata essential oil, the antimicrobial activity of the essential oil was examined in the present study. Interestingly, reports from literature on the association between the essential oil phytochemical composition and its antimicrobial activity are found to be in great consistency with the findings of the present study. In particular, oxygenated monoterpenes were evidently reported as potent antimicrobial agent in the composition of several essential oils [42]. In addition, 1,8-cineole and sesquiterpenes were shown to exhibit considerable antimicrobial activity against a wide range of Gram-positive and Gram-negative bacteria [42, 43]. However, as essential oils contain multiple components, their antimicrobial activities are rather due to additive, synergistic or antagonistic effects of the individual constituents.

Additionally, the results of the ABTS and FRAP assays revealed that $M$. spicata essential oil possessed reasonable antioxidant activity in the two assays. This could be attributed to the presence of high quantity of carvone in sample. In addition, it has been previously reported that compounds such as monoterpenes, and oxygenated monoterpenes may have antioxidant potential equivalent to that of a strong antioxidant [44]. Nonetheless, non-phenolic terpenoids were also reported to have substantial antioxidant potential [45]. Moreover, the observed antioxidant activity might be attributed to several other components of essential oils, including $\alpha$-terpinene and 1,8-cineole [5, 46]. Accordingly, the abundance of potent antioxidants ingredients in the chemical composition of $M$. spicata oil would reasonably rationalize its moderate antioxidant activity.

Despite the endogenous antioxidant defense mechanisms, cell damage from oxygen free radicals is ubiquitous. Evidence has begun to accumulate supporting the critical role of free radicals in the initiation and development of cancer [47]. Literature reports have demonstrated that antioxidants may slow or possibly counteract cancer development and progress [48]. In this study, the observed anticancer activity of $M$. spicata oil might be linked to its ability to neutralize free radicals in cancer cells. Tumor cells survive by complex molecular signaling pathways. Targeting the different signaling pathways, by multiple agents, to block, retard, or reverse the tumorigenesis has been an effective strategy in cancer chemoprevention and chemotherapy. Essential oils are among of the most beneficial plant products utilized in medicine and complementary treatment approaches. Since M. spicata essential oil is generally recognized as safe, and thus widely used in food additives and cosmetics, the results of this study support the use of this oil as a potential source of new active anticancer agent. In order to assess the applied value of this potential therapeutic application, further investigation into the different mechanisms of action of the multiple components of the oil should be carried out.

\section{Conclusion}

In summary, results of the current study revealed that the essential oil of $M$. spicata demonstrated moderate bioactivity elucidated by its antioxidant, antimicrobial and anticancer potential. These results suggest that the bioactive oil can be beneficially employed in pharmaceutical industries as well as in food production technologies.

\section{Funding \\ This research was supported by The Deanship of Academic Research at The University of Jordan (1786).}

\section{Availability of data and materials}

The data that support the findings of this study are available from the corresponding author on reasonable request.

\section{Authors' contributions \\ SB designed and performed the experiments, interpreted the results, drafted the manuscript and revised it. BB collected the plant, isolated the essential oil, characterized the antioxidant activity of the oil, drafted the manuscript and participated in the design of the study. HA prepared and evaluated the results and participated in writing the manuscript. MR, AG and GF conducted the chemical composition analysis, performed the statistical analysis and participated in drafting the manuscript. All authors read and approved the final manuscript.}

\section{Ethics approval and consent to participate}

Not applicable.

\section{Consent for publication}

Not applicable.

\section{Competing interests}

The authors declare that they have no competing interests.

\section{Publisher's Note}

Springer Nature remains neutral with regard to jurisdictional claims in published maps and institutional affiliations.

\section{Author details}

'Department of Pharmaceutical Sciences, School of Pharmacy, University of Jordan, Queen Rania Street, Amman 11942, Jordan. ${ }^{2}$ Laboratory of Process Engineering, Faculty of Technology, Laghouat University, 03000 Laghouat, Algeria. ${ }^{3}$ Dipartimento di Farmacia, Università di Pisa, Via Bonanno 6, 56126 Pisa, Italy. 
Received: 20 March 2018 Accepted: 27 June 2018 Published online: 03 July 2018

\section{References}

1. Bakkali F, et al. Biological effects of essential oils-a review. Food Chem Toxicol. 2008;46(2):446-75.

2. Edris AE. Pharmaceutical and therapeutic potentials of essential oils and their individual volatile constituents: a review. Phytother Res. 2007;21(4):308-23.

3. Bardaweel SK, et al. Studies on the in vitro antiproliferative, antimicrobial, antioxidant, and acetylcholinesterase inhibition activities associated with Chrysanthemum coronarium essential oil. Evid Based Complement Alternat Med. 2015;2015:6. Article ID 790838.

4. Bardaweel S, Hudaib M, Tawaha K. Evaluation of antibacterial, antifungal, and anticancer activities of essential oils from six species of eucalyptus. J Essent Oil Bear Plants. 2014;17(6):1165-74.

5. Bardaweel SK, Tawaha KA, Hudaib MM. Antioxidant, antimicrobial and antiproliferative activities of Anthemis Palestina essential oil. BMC Complement Altern Med. 2014;14(1):297.

6. Tardugno R, et al. Chemical profile and biological activities of Cedrelopsis grevei H. Baillon bark essential oil. Plant Biosyst. 2018;152(1):120-9.

7. Spagnoletti A, et al. Chemical composition and bio-efficacy of essential oils from italian aromatic plants: Mentha suaveolens, Coridothymus capitatus, Origanum hirtum and Rosmarinus officinalis. Nat Prod Commun. 2016; 11(10):1517-20.

8. Rossi D, et al. Croton lechleri Müll. Arg.(Euphorbiaceae) stem bark essential oil as possible mutagen-protective food ingredient against heterocyclic amines from cooked food. Food Chem. 2013:139(1-4):439-47.

9. Maietti $\mathrm{S}$, et al. A multivariate analysis approach to the study of chemical and functional properties of chemo-diverse plant derivatives: lavender essential oils. Flavour Fragrance J. 2013;28(3):144-54.

10. Celenk S, et al. A palynological study of the genus Mentha L.(Lamiaceae). Bot J Linn Soc. 2008:157(1):141-54.

11. Fenwick $A$, Ward S. Use of random amplified polymorphic DNA markers for cultivar identification in mint. HortScience. 2001:36(4):761-4.

12. Gobert $V$, et al. Hybridization in the section Mentha (Lamiaceae) inferred from AFLP markers. Am J Bot. 2002;89(12):2017-23.

13. Shasany $A$, et al. Use of RAPD and AFLP markers to identify inter-and intraspecific hybrids of Mentha. J Hered. 2005:96(5):542-9.

14. Rösch P, Kiefer W, Popp J. Chemotaxonomy of mints of genus Mentha by applying Raman spectroscopy. Biopolymers. 2002:67(4-5):358-61.

15. Asekun O, Grierson D, Afolayan A. Effects of drying methods on the quality and quantity of the essential oil of Mentha longifolia L. subsp. Capensis. Food Chem. 2007;101(3):995-8.

16. Al-Bayati FA. Isolation and identification of antimicrobial compound from Mentha longifolia L. leaves grown wild in Iraq. Ann Clin Microbiol Antimicrob. 2009;8(1):20.

17. Mahboubi M, Haghi G. Antimicrobial activity and chemical composition of Mentha pulegium L. essential oil. J Ethnopharmacol. 2008;119(2):325-7.

18. Isscan $\mathrm{G}$, et al. Antimicrobial screening of Mentha piperita essential oils. J Agric Food Chem. 2002;50(14):3943-6.

19. Pandey A, Rai M, Acharya D. Chemical composition and antimycotic activity of the essential oils of corn mint (Mentha arvensis) and lemon grass (Cymbopogon flexuosus) against human pathogenic fungi. Pharm Biol. 2003:41(6):421-5.

20. Lawrence BM. The composition of commercially important mints. In: MintThe Genus Mentha. NY: CRC press, Taylor and Francis Group; 2007. p. 280.

21. Mata A, et al. Antioxidant and antiacetylcholinesterase activities of five plants used as Portuguese food spices. Food Chem. 2007;103(3):778-86.

22. AOAC. Official methods of analysis of the Association of Official Analytical Chemists (AOAC). 15th ed. Virginia: AOAC Inc.; 1990.

23. Adams RP. Identification of essential oil components by gas chromatography/mass spectrometry. 4th ed. USA: Allured Pub Corp; 2007.

24. Davies NW. Gas chromatographic retention indices of monoterpenes and sesquiterpenes on methyl silicone and Carbowax 20M phases. J Chromatogr. 1990:503(1):1-24

25. Boulanouar B, et al. Antioxidant activities of eight Algerian plant extracts and two essential oils. Ind Crop Prod. 2013;46:85-96.

26. Re $\mathrm{R}$, et al. Antioxidant activity applying an improved ABTS radical cation decolorization assay. Free Radic Biol Med. 1999;26(9-10):1231-7.
27. Oyaizu M. Studies on products of browning reaction. Japanese J Nutr Diet 1986:44(6):307-15.

28. European Committee for Antimicrobial Susceptibility Testing (EUCAST) of the European Society of Clinical Microbiology and Infectious Diseases (ESCMID). Determination of minimum inhibitory concentrations (MICS) of antibacterial agents by agar dilution. Clin Microbiol Infect. 2000;6:509-15.

29. Ferraro MJ, N.C.f.C.L. Standards. Methods for dilution antimicrobial susceptibility tests for bacteria that grow aerobically : approved standard. 5 ed.. NCCLS; M7-A5 = v. 20, no. 2 ISSN 0273-3099. 2000. United States: Wayne, PA: NCCLS; 2000

30. Nickavar B, Alinaghi A, Kamalinejad M. Evaluation of the antioxidant properties of five Mentha species. Iranian J Pharm Res. 2008;7:203-9.

31. Kizil S, et al. Mineral content, essential oil components and biological activity of two mentha species (M. Piperita L., M. Spicata L.). Turkish J Field Crops. 2010;15(2):148-53.

32. Gharib F, da Silva JT. Composition, total phenolic content and antioxidant activity of the essential oil of four Lamiaceae herbs. Med Aromat Plant Sci Biotechnol. 2013;7(1):19-27.

33. Meir $\mathrm{S}$, et al. Determination and involvement of aqueous reducing compounds in oxidative defense systems of various senescing leaves. J Agric Food Chem. 1995;43(7):1813-9.

34. Yang $C$, et al. Antioxidant and anticancer activities of essential oil from Gannan navel orange peel. Molecules. 2017;22(8):1391.

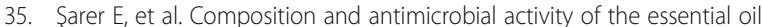
from Mentha spicata L. subsp. spicata. J Essent Oil Res. 2011;23(1):105-8.

36. Shahbazi Y. Chemical composition and in vitro antibacterial activity of Mentha spicata essential oil against common food-borne pathogenic bacteria. J Pathogens. 2015;2015:5. Article ID 916305.

37. Snoussi M, et al. Mentha spicata essential oil: chemical composition, antioxidant and antibacterial activities against planktonic and biofilm cultures of Vibrio spp. strains. Molecules. 2015;20(8):14402-24.

38. Brahmi F, et al. Chemical and biological profiles of essential oils from Mentha spicata L. leaf from Bejaia in Algeria. J Essent Oil Res. 2016;28(3):211-20.

39. Fitsiou $\mathrm{E}$, et al. Phytochemical profile and evaluation of the biological activities of essential oils derived from the Greek aromatic plant species Ocimum basilicum, Mentha spicata, Pimpinella anisum and Fortunella margarita. Molecules. 2016;21(8):1069.

40. Allali $\mathrm{H}$, et al. Antioxidant activity and chemical analysis of Mentha spicata cultivated from west northern region of Algeria by headspace solid phase micro-extraction and hydro-distillation. Nat Prod. 2013;9(6):258-63.

41. Laggoune S, Öztürk M, Erol E, Duru ME, Abaza I, Kabouche A, Kabouche Z Chemical composition, antioxidant and antibacterial activities of the essential oil of Mentha spicata L from Algeria. J Mater Environ Sci. 2016;7(11):4205-13.

42. Knobloch $\mathrm{K}$, et al. Antibacterial and antifungal properties of essential oil components. J Essent Oil Res. 1989;1(3):119-28.

43. Baratta MT, et al. Antimicrobial and antioxidant properties of some commercial essential oils. Flavour Fragrance J. 1998;13(4):235-44.

44. Ruberto $G$, et al. Antioxidant and antimicrobial activity of Foeniculum vulgare and Crithmum maritimum essential oils. Planta Med. 2000;66(08):687-93

45. Ruberto G, Baratta MT. Antioxidant activity of selected essential oil components in two lipid model systems. Food Chem. 2000;69(2):167-74.

46. Shaaban HA, El-Ghorab AH, Shibamoto T. Bioactivity of essential oils and their volatile aroma components. J Essent Oil Res. 2012;24(2):203-12.

47. Dreher D, Junod AF. Role of oxygen free radicals in cancer development. Eur J Cancer. 1996:32A(1):30-8.

48. Islam $\mathrm{S}$, et al. Evaluation of antioxidant and anticancer properties of the seed extracts of Syzygium fruticosum Roxb. growing in Rajshahi, Bangladesh. BMC Complement Altern Med. 2013;13:142. 